\title{
A CULTURA HISTÓRICA COMO POSSIBILIDADE INVESTIGATIVA A PARTIR DE HISTÓRIAS EM QUADRINHOS (AUTO)BIOGRÁFICAS COM PERSONAGENS HISTÓRICOS LATINO-AMERICANOS
}

THE HISTORICAL CULTURE AS AN INVESTIGATIVE POSSIBILITY FROM (SELF)BIOGRAPHICAL COMIC BOOKS WITH LATIN AMERICAN HISTORICAL FIGURES

\author{
Marcelo Fronza* \\ fronzam34@yahoo.com.br
}

RESUMO: Este estudo investiga como a cultura histórica latino-americana está relacionada com a forma como os jovens tomam o conhecimento para si a partir de histórias em quadrinhos (auto)biográficas. A investigação é estruturada nas relações entre a cultura jovem, as histórias em quadrinhos e a cultura histórica de uma sociedade. Parte-se da preocupação de compreender os processos históricos vinculados à relação entre a interculturalidade e o novo humanismo (RÜSEN, 2014) e o princípio da "burdening history" proposto Bodo von Borries (2016), o qual propõe que o fardo da história pode ser superado pela interpretação multiperspectivada instauradora de controvérsia provida pela autocrítica na teoria da história (FREITAS, 2017). Analisam-se historias em quadrinhos que narram experiências (auto)biográficas de sujeitos que enfrentaram e resistiram à escravidão, à violência política e ao racismo na América Latina e participaram dos processos revolucionários de Cuba. Além disso, o gênero (auto)biográfico nos quadrinhos é fundamental para a compreensão da imagem pública dos sujeitos.

PALAVRAS CHAVE: Educação Histórica, Cultura histórica latino-americana, Histórias em quadrinhos (auto)biográficas.

ABSTRACT: : This study investigates how Latin American historical culture is related to the way in which young people take knowledge of themselves from (self) biographical comic book. Research is structured in the relationships between youth culture, comic books, and the historical culture of a society. It begins with the concern to understand the historical processes linked to the relationship between interculturality and the new humanism (RÜSEN, 2014) and the principle of "burdening history" proposed by Bodo von Borries (2016), which proposes that the burden of history can to be overcome by the multiperspectivity way of interpretation instituting controversy provided by selfcriticism in the theory of history (FREITAS, 2017). It analyzes comic books that narrate thee (self) biographical experiences of subjects who faced and resisted slavery, political violence and racism in Latin America and participated in the revolutionary processes of Cuba. In addition, the (auto) biographical genre in the historical comic books is fundamental for the understanding of the public image of the subjects.

KEYWORDS: History Education, Latin American historical culture, (Self)biographical comic books.

\section{Introdução}

Este trabalho é produzido a partir do grupo de professores historiadores ligado ao Laboratório de Pesquisa em Educação História, da Universidade Federal do Paraná (LAPEDUH/UFPR), e faz parte do projeto de pesquisa Os jovens e as ideias de verdade histórica e intersubjetividade na relação com as narrativas históricas visuais, vinculado ao Grupo de Pesquisa em Educação Histórica: Consciência Histórica e Narrativas Visuais

*Doutorado em Educação pela Universidade Federal do Paraná. Sou também professor de História da escola pública no Paraná 
(GPEDUH/UFMT), da Universidade Federal do Mato Grosso. Insere-se no conjunto de pesquisas relativas à linha de investigação ligada à cognição histórica situada (SCHMIDT, 2009), a qual tem como fundamento a própria ciência da História e estruturam a área de pesquisa da Educação Histórica, um campo de investigação que estuda as ideias históricas dos sujeitos em contextos de escolarização. Nela, as pesquisas empíricas dialogam com a teoria da consciência histórica (RÜSEN, 2001, 2012).

Esta investigação tem como objetivo compreender como os artefatos da cultura histórica estão relacionados com a forma como os jovens tomam o conhecimento para si a partir de histórias em quadrinhos (auto)biográficas que narram as experiências históricas de sujeitos latino-americanos. Em minhas pesquisas, encontrei um tipo de investigação peculiar relativa ao modo como as narrativas históricas gráficas entraram na cultura escolar no Ocidente: a introdução, nas escolas, de quadrinhos biográficos, autobiográficos ou investigativos sobre pessoas que viveram alguns dos grandes eventos históricos da modernidade (WITEK, 1989; GUNDERMANN, 2007).

Neste artigo investigo as experiências (auto)biográficas de sujeitos que enfrentaram e resistiram à escravidão, à violência política e ao racismo na América Latina e participaram do processo revolucionário de Cuba. Minha preocupação é entender os processos históricos ligados à relação entre a interculturalidade e o novo humanismo (RÜSEN, 2014) e o princípio da "burdening history" proposto por Bodo von Borries (2016), que entendem que o fardo da história pode ser superado pela interpretação multiperspectivada instituída na controvérsia proporcionada pela autocrítica na teoria da história (FREITAS, 2017).

É nesse sentido que tais artefatos da cultura histórica podem se estruturar em narrativas (auto)biográficas, permitindo aos jovens formar um sentido de orientação temporal que se fundamente no autoconhecimento a partir da práxis social do outro. Segundo Ludmila Jordanova (2006), a biografia deve ser entendida para além de um gênero literário. Isso porque ela considera o sujeito como uma unidade de análise dentro de uma abordagem histórica particular, na qual a ação da individualidade é a convergência de diversas forças históricas que englobam um momento da vida humana numa temporalidade histórica da humanidade. 


\section{As histórias em quadrinhos (auto)biográficas como possibilidade das ideias interculturais na Educação História}

As histórias em quadrinhos são compreendidas como artefatos narrativos da cultura juvenil que permitem aos jovens desenvolver uma relação de intersubjetividade com o conhecimento histórico. Por isso, é vital investigar o que, para os jovens, é plausível nas narrativas históricas gráficas e qual é a especificidade que a relação de intersubjetividade com a História fornece ao processo de formação de sua identidade. Entendo que a cultura juvenil, no âmbito da cultura escolar, manifesta, nos estudantes, uma determinada forma de operar historicamente com os quadrinhos.

Essa possibilidade investigativa das histórias em quadrinhos (auto)biográficas voltadas para a aprendizagem histórica ainda é pouco pesquisada no ensino de História, necessitando ser mais bem investigada no campo de pesquisa da Educação Histórica, mesmo considerando que, no campo da historiografia da linguagem dos quadrinhos, já existam alguns trabalhos. Seu perfil se caracteriza por investigar narrativas históricas gráficas de caráter biográfico, autobiográfico e ou até mesmo investigativo sobre sujeitos e grandes eventos históricos significativos para a história da humanidade.

As (auto)biografias são gêneros que expressam a memória histórica de sujeitos que ajudam a compreender as relações humanas estruturadas em determinadas comunidades. Segundo Saliba (2009), são histórias de produção maciça que dizem respeito a uma dimensão pedagógica da História. Estão estritamente vinculadas ao aumento da capacidade de armazenamento de informações do passado e à velocidade temporal das mudanças que modificam radicalmente a experiência histórica contemporânea. As biografias vinculam-se a uma história de circulação massiva que podem estiolar as concepções de tempo e de passado. Por outro lado, podem também, a partir de sua função didática, sustentar versões na esfera pública que permitam responder algumas perguntas sobre o passado humano, isso porque podem fornecer um sentido de orientação temporal que sustente ações que valorizem a subjetividade humana. Isso se evidencia ao apresentar narrativas:

sobre como é o mundo, como as coisas têm de ser e o que nos reserva o futuro, ou seja, aquilo que o mundo de hoje não tem. Podemos chamar isso de teoria, mito, ideologias, ilusões [...], mas o fato é que, apesar de estarmos em crise, não cessamos de ansiar ou criar histórias e futuros para nós mesmos por meio de alguma narrativa. Sem uma narrativa a vida não tem sentido. Sem um sentido a aprendizagem da história não tem um 
significado. Sem um significado não superamos a necessidade de gerar sentido para a vida (SALIBA, 2009, p. 62-63).

Nesse sentido, cabe ao professor historiador estimular em seus estudantes o aumento do quadro histórico de referências significativas sobre o passado, tornando-se um provocador das inquietudes ao mobilizar (auto)biografias que incentivem o imprevisível, que provoquem a imaginação dos jovens estudantes (SALIBA, 2009). Tal atitude pode contribuir para a compreensão da alteridade própria da constituição da memória histórica da humanidade.

Segundo Rocco Versaci (2007, p. 38-39), as histórias em quadrinhos (auto)biográficas apresentam modos de expressão da perspectiva em primeira pessoa que vão além da escrita. É possível que o personagem (auto)biografado realize uma conversa direta com o leitor por meio dos balões de fala. Isso permite uma relação de intimidade entre o autor e o leitor. Além disso, outro recurso dos quadrinhos são os balões de pensamento, onde o autor cria uma imagem de um cenário que revela a "janela secreta" dos pensamentos e sentimentos do (auto)biografado. Esses artefatos da cultura histórica tornam possíveis as representações de ideias conscientes e inconscientes do sujeito, tais como traumas, sonhos, desejos e projetos de futuro. Outro elemento da linguagem dos quadrinhos é a caixa de texto ou box, que além de indicar uma narrativa em primeira ou terceira pessoas permite uma disjunção entre autor e (auto)biografado, em que a imagem visual recria o sujeito no passado, porém, no texto quadrinizado, endereça a voz autoral a vários momentos do tempo, incluindo a voz do "presente" refletindo os acontecimentos do passado.

Além disso, o gênero biográfico é fundamental para a compreensão da imagem pública dos sujeitos. Philip Lejeune (1996) compreende que nas autobiografias existe um pacto entre o escritor (no caso das narrativas gráficas autobiográficas, os quadrinistas) e o leitor. Com isso, existe uma ampliação dos espaços narrativos do eu como uma mediação entre o público e o privado (ARFUCH, 2010).

A diferença em potencial deste tipo de investigação é que as histórias em quadrinhos passam a ser perspectivadas, a partir do princípio epistemológico da narrativa histórica, como uma forma de expressão da orientação de sentido no tempo dos sujeitos que expressam o diálogo entre as experiências de sofrimento do passado que constituem as 
interpretações e problematizações do presente e estruturam as perspectivas interculturais de futuro.

A cultura histórica, expressão da memória histórica de uma comunidade (RÜSEN, 1994) que está baseada no princípio da narrativa, pode ordenar temporalmente os procedimentos da cultura escolar, a partir da experiência que os jovens têm com o conhecimento. Para isso, compreendo ser necessário ter como critério de verdade básico uma intersubjetividade pautada em narrativas históricas com valores ligados à humanidade enquanto igualdade. Assim sendo, a cultura histórica estrutura as expressões de uma unidade de consciência às estratégias científicas, às formas da criação artística, à educação, à luta pelo poder ligados aos procedimentos da memória histórica pública (RÜSEN, 1994).

É por causa da função narrativa, estruturada por um fio condutor de sentido, que as histórias em quadrinhos e outras narrativas históricas visuais podem contribuir para esse processo de libertação dos sujeitos. A função narrativa das histórias em quadrinhos diz respeito às formas de expressão da cultura jovem. A "unidade global da memória histórica", expressa no narrar dos sujeitos, sintetiza e integra as funções da legitimação, da crítica, do ensino, do entretenimento, das imagens e dos mais variados modos de rememorar o passado. A rememoração histórica se dá por meio de uma operação mental do "ato de contar histórias". A plausibilidade narrativa ligada à consciência histórica transforma o procedimento mental da rememoração histórica em formas de narrar a História (RÜSEN, 1994, p. 8-9).

Seguindo esse caminho, entendo que as considerações teóricas advindas do investigador James V. Wertsch (WERTSCH \& ROZIN, 2004) podem ser úteis na compreensão das narrativas históricas gráficas. Utilizando o conceito de "dialogicidade oculta", criado por Mikhail Bakhtin (1997), James Wertsch e Mark Rozin investigaram as narrativas produzidas entre 1992 e 1993 por cidadãos russos da antiga URSS sobre como representam o passado (especificamente a revolução de 1917. Para esses autores essas narrativas são "objetos de resistência" ou "contratextos" em relação às narrativas históricas oficiais daquela antiga confederação de nações.

Sabe-se que a narrativa gráfica é uma das conceitualizações estruturantes das histórias em quadrinhos e isto possibilita que os jovens desenvolvam a capacidade de reconstruir suas ideias na forma de uma narrativa. 
Com isso, ao investigar as as histórias em quadrinhos (auto)biográficas sobre as experiências de sofrimento e luta na América Latina, os embates presentes na dimensão estética das histórias em quadrinhos que podem revelar, seja um conjunto de imagens canônicas (SALIBA, 1999), seja uma criação ativa por meio dessas imagens (LUKÁCS, 2003, 2010).

Para Elias Thomé Saliba, o professor de história, juntamente com seus alunos, poderia fazer um ordenamento do tempo que supere o presentismo inerente às imagens canônicas e dominantes na condição juvenil. Saliba compreende o ordenamento no tempo como uma "operação crítica" de comparação, aproximação e distanciamento temporal das imagens e seus significados. Em proximidade com as ideias de Lukács (2010), afirma que criticar as imagens é tentar "quebrar com o efeito de real que elas provocam" (SALIBA, 1999, p. 440). Para isso, é necessário sintetizar a análise das imagens contra a superabundância na mídia e na sociedade.

O uso de imagens alternativas, que causem os sentimentos estéticos da indignação, da esperança e do humor, pode ser vital porque possibilitam a consciência do distanciamento entre o passado e o presente, abrindo espaço, assim, para um primeiro passo de um processo de ordenamento do tempo.

Bakhtin (2000) atentou para os valores que as imagens podem revelar no diálogo com outras imagens pertencentes a outras épocas passadas da grande temporalidade da humanidade; e McCloud (2006) indicou que, ao contrário das imagens representadas em um eterno presente, as histórias em quadrinhos, em sua narrativa, apresentam um mapa temporal onde a experiência do passado, do presente e do futuro estão unidas graficamente.

As imagens canônicas dificultam diálogos, a não ser os estereotipados. Já as imagens alternativas se sustentam nesses diálogos, mesmo quando implícitos. Para Bakhtin as ideias, na dimensão da práxis vital, não estão restritas à consciência individual, mas sim à comunicação dialogada entre as consciências. "A ideia é um acontecimento vivo que irrompe no ponto de contato dialogado entre duas ou várias consciências" demarcando, assim, seu posicionamento perante o mundo da vida prática. Só é possível se relacionar em relação à posição do outro, como uma resposta ao outro. Dessa forma, as ideias assumem a complexidade contraditória de uma "ideia-força, que nasce, vive e atua no grande diálogo da 
época e guarda semelhança com as ideias cognatas de outras épocas". A relação temporal entre as ideias as transformam em imagem: a imagem de uma ideia. Como ela se constituiu na relação dialógica com outras ideias do passado e com as que ainda estão nascendo para se expandir no futuro, a ideia tornada imagem é sempre "interindividual e intersubjetiva" e, portanto, intercultural (BAKHTIN, 1997, p. 87-88).

A partir da ideia que a natureza narrativa das histórias em quadrinhos transforma as operações mentais da consciência histórica, cheguei a seguinte constatação: entendo que as histórias em quadrinhos (auto)biobráficas possibilitam o aparecimento de construtos de narrativas históricas sofisticadas em relação às experieêncvias históricas da América Latina, por meio da mobilização, pelos sujeitos, das ideias relativas à interculturalidade.

Segundo Jörn Rüsen (2014, p. 296), a interculturalidade parte do princípio do reconhecimento igualitário da diferença cultural que ultrapassa o entendimento etnocêntrico baseado na tolerância dada pelos civilizados aos não civilizados. As lutas pelo reconhecimento estão na base dos conflitos culturais contemporâneos. Contudo, é no campo desses conflitos que as chances de comunicação intercultural se fazem valer, pois as "culturas se interpenetram, delimitam-se umas em relação às outras, combatem-se, aprendem umas das outras e se modificam no relacionamento mútuo". Essa comunicação intercultural humanista se faz por meio de narrativas históricas em constantes diálogos.

Se entendermos que o fardo da história pode ser superado pela interpretação multiperspectiva instituída da controvérsia proporcionada pela autocrítica na teoria da história (FREITAS, 2017), podemos apreender que lidar com o fardo da história é um problema relativo às operações mentais da narrativa histórica. De acordo com Bodo von Borreis (2016), existem formas de se lidar com histórias difíceis. Em suas investigações construiu uma tipologia das formas narrativas que se apresentam os fardos da história: 1) histórias hostis baseadas em um modelo de vingança e "rivalidade de sangue" (inimizade herdada) vinculadas a investigações empíricas da cultura histórica (autobiografias, romances, entrevistas, narrativas históricas); 2) a história dos vencedores e da perda/esquecimento dos perdedores (cinismo do poder); 3) a história oculta e subalterna dos perdedores e a esperança de uma rememoração histórica (rememoração heróica); 4) o abandono e esquecimento de uma história hostil devido sua irrelevância na vida prática dos envolvidos (prioridade pela sobrevivência em momentos violentos). Essas histórias foram 
geradas pelo sofrimento e não permitem alcançar uma reconciliação histórica (BORRIES, 2016, p. 32-33).

Alcançar uma reconciliação entre antigos inimigos (vítimas e algozes) é uma experiência histórica de um movimento em direção de uns relação aos outros e uma busca por continuar a seguir o mesmo caminho juntos. O caminho que possibilita que os humanos se tornem mais humanos (BORRIES, 2016, p. 33).

É possível desenvolver estratégias mentais de reconciliação histórica por meio das narrativas históricas, dentre elas as histórias em quadrinhos (auto)biográficas. Entre os primeiros passos dessa reconciliação está a necessidade de abolir as falsificações e mitos tendenciosos, distanciando-se do passado de sofrimento e rivalidade, sem, no entanto, esquecê-lo. Dentre os passos intermediários está o movimento de uns em direção aos outros buscando caminhar juntos para construir as chances e condições de um futuro comum. Por fim, é necessário apostar em passos claros e firmes em direção à mutualidade, construindo histórias novas, plausíveis e compatíveis, mesmo que ao menos parcialmente comuns e com isso, desenvolvendo o reconhecimento dos "outros" e a aceitação e internalização mútua na própria história (BORRIES, 2016, p. 40-41).

A narrativa se estrutura na concepção básica de que alguém conta a alguém uma história sobre uma experiência do passado interpretada no presente e que cria expectativas de futuro, tal como expressa a história em quadrinhos sul-africana Vusi goes back. A comic book about the history of South Africa.

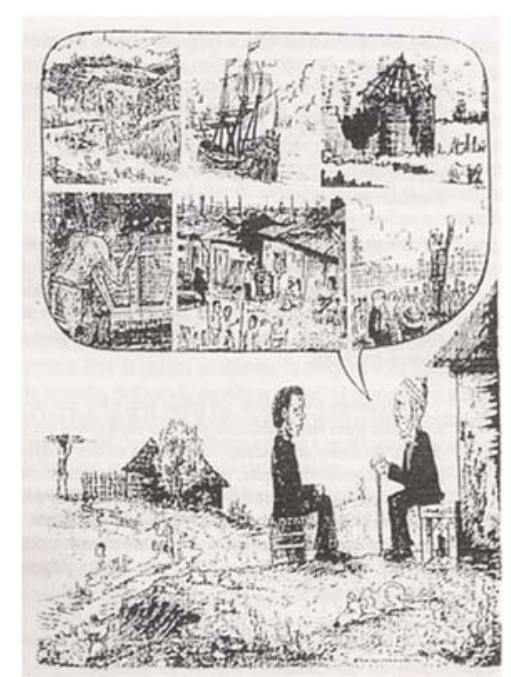

Imagem 1 - Vusi goes back. A comic book about the history of South Africa. (Prezanian Comix, E.D.A.); de um manual para "trabalhadores comunitários", 1981, fig. p. 2. (RÜSEN, 2001, p. 158) 
Essa história em quadrinhos narra um versão da história sul-africana, desde sua origem até os movimentos de resistência antiapartheid, e busca construir um ordenamento temporal do conteúdo a partir da estrutura básica da narrativa. Creio que é importante ler qualquer história em quadrinhos a partir dos diálogos dos seus personagens, pois ali são expressas as ideias que problematizam as carências da práxis vital. Portanto, é a estrutura narrativa e dialógica que define as histórias em quadrinhos (auto)biográficas.

\section{Para uma investigação sobre as histórias em quadrinhos (auto)biográficas no interior da cultura histórica latino-americana}

Nesta pesquisa investigo imagens alternativas às canônicas (SALIBA, 1999) e as narrativas esquemáticas (WERTSCH, 2006) vinculadas às identidades nacionais. Portanto, busco indícios de contranarrativas históricas que, na práxis vital contemporânea dos movimentos sociais latino-americanos, em alguns casos, acabaram por se tornar narrativas mestras contra-hegenônicas.

Encontrei dois tipos de narrativas históricas sobre as experiências políticas de resistência dos sujeitos latino-americanos quadrinizadas em (auto)biografias ${ }^{1}$ : a) as histórias em quadrinhos que personalizam as experiências (auto)biográficas de sujeitos afro-latinos que enfrentaram e resistiram à escravidão, à violência política e ao racismo na América Latina; b) Histórias em quadrinhos que personalizam as narrativas históricas sobre os processos revolucionários tais como os de Cuba, assim como da resistência armada vinculada à violência política na Colômbia. Essas dois tipos de contranarrativas atestam uma geração de sentido histórico (RÜSEN, 2015).

\section{a) Histórias em quadrinhos que personalizam as experiências (auto)biográficas de sujeitos afro-latinos na América Latina}

\footnotetext{
${ }^{1}$ Existe um terceiro tipo de narrativa histórica muito presente nas lutas identitárias latino-americanas: a narrativa sobre as comunidades e nações indígenas da América Latina pré-colombiana. Não a abordei aqui por três motivos: 1) em praticamente todos os países latino-americanos de colonização espanhola e portuguesa a mitificação do indígena é uma presença constante nas identidades nacionais, portanto, de certa forma, fazem parte de uma narrativa mestra dessas nações em relação à conquista europeia e à independência política (em que pese, que as experiências históricas de resistência indígena à conquista e a colonização da América podem gerar contranarrativas fundamentais para a construção de histórias contra-hegenônicas no continente). 2) Exatamente por causa do potencial contranarrativo das experiências indígenas em prol da luta pela autonomia cultural investiguei o modo como o encontro entre indígenas e europeus durante a conquista da América é compreendido por jovens estudantes brasileiros em outros trabalhos. 3) Ainda estou inventariando mais narrativas históricas gráficas sobre o tema buscando histórias em quadrinhos que narram a experiência indígena de resistência em vários países da América Latina. Em futuros trabalhos também investigarei histórias em quadrinhos que narrem as experiências dos sujeitos que participaram da Revolução Mexicana.
} 
Esse tipo de histórias em quadrinhos (auto)biográficas aborda as experiências do passado de afro-latinos ${ }^{2}$ (ANDREWS, 2014) em relação à resistência ao sistema escravista e ao racismo, seja por meio da formação de quilombos, seja a partir da revolta política. No caso da América portuguesa e do Brasil imperial, organizações em quilombos e revoltas políticas faziam parte de uma mesma experiência histórica como no caso do quilombo dos Palmares (hoje estado de Alagoas) e do conflito da Balaiada, no Maranhão.

Um exemplo desse tipo de narrativa biográfica é a história em quadrinhos Angola Janga de autoria do quadrinista Marcelo D'Salete (2017). A dimensão estética neste artefato da cultura histórica é marcante nessa obra, pois é claramente vinculada à arte figurativa africana e afro-brasileira. O nome Angola Janga, na língua banto quimbundo, significava "Pequena Angola", nome pelo qual provavelmente Palmares era chamado por seus moradores. Pauta-se numa contranarrativa em relação à história tradicional da colonização da América portuguesa do século XVII (essa história tradicional aparece sob a forma de documentos de época que estão dispostos no início de cada capítulo). Isso porque é construída a partir do ponto de vista dos quilombolas que formaram o quilombo dos Palmares (que pode ser considerado uma espécie de confederação de mocambos com aproximadamente 20.000 habitantes, cuja capital era Macaco) na serra da Barriga, por meio de valores culturais de matriz africana em contraponto à economia de plantation ${ }^{3}$ desenvolvida por holandeses e portugueses no leste do continente americano.

\footnotetext{
2 Utilizo os conceitos de sujeitos afro-latinos e América Afro-Latina desenvolvidos pelo historiador George Reid Andrews (2014) que o redefiniu a partir das categorizações dos cientistas políticos Anani Dzidzienyo e PierreMichel Fontaine. América Afro-Latina se refere "a todas as regiões da América Latina em que são encontrados grupos significantes de pessoas de conhecida ascendência africana" (FONTAINE apud ANDREWS, 2014, p. 29). Nessa definição estão incluídos sujeitos definidos como "pardos" pelas instituições oficiais das nações latinoamericanas. Existe uma definição mais exclusiva, a de sujeitos afro-latinos, sustentada pela categoria da "diáspora", que não se concentra em regiões geográficas, mas em sujeitos (grupos e indivíduos) que se identificam como de ascendência africana, quer por si próprios quer pela sociedade em que vivem. A partir de Andrews (2014, p. 32-33) considero as duas definições válidas e intercambiáveis para essa investigação.

3 Plantation é uma fazenda que utiliza mão-de-obra intensivamente. No caso da América Latina predominaram plantations de cana-de-açúcar e café sob um regime de trabalho escravista (ANDREWS, 2014, p. 30n).
} 


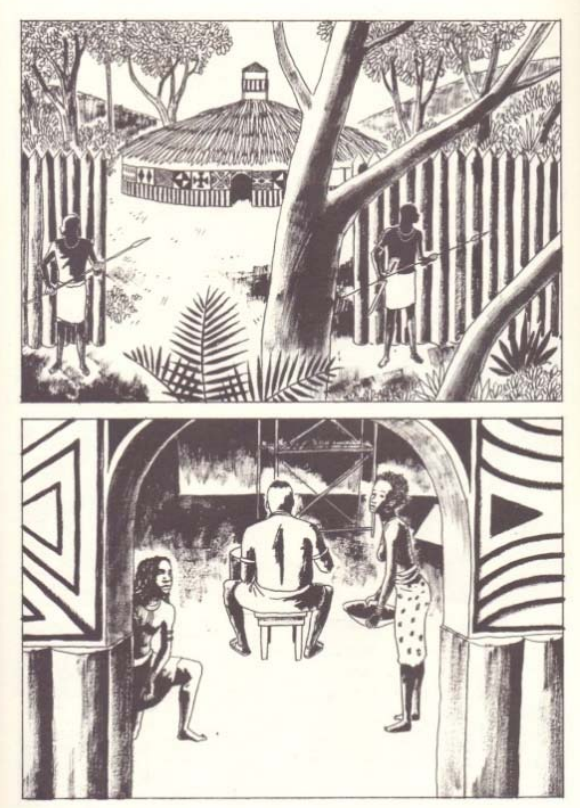

Imagem 2 - D’SALETE, Marcelo. Angola Janga: uma história de Palmares. São Paulo: Veneta, 2017, p. 83.

A narrativa gráfica aborda os anos de domínio de Ganga-Zumba as batalhas contra expedições portuguesas e bandeirantes que levaram à morte do último rei de Palmares, Zumbi. Ao apresentar a tentativa de acordo de paz com Recife proposta por Ganga-Zumba, sendo constantemente minada pelos ataques advindos de colonizadores portugueses e bandeirantes, a história em quadrinhos narra a ascensão de Zumbi como líder guerreiro de Palmares. O domínio de Ganga-Zumba é apresentado de modo que as dimensões políticas, morais e religiosas da cultura histórica daquela comunidade foram pautadas numa tentativa de relacionamento intercultural de reconhecimento mútuo dos diversos mocambos de Palmares com os indígenas, as fazendas, vilas e cidades brasílicas da capitania de Pernambuco. 


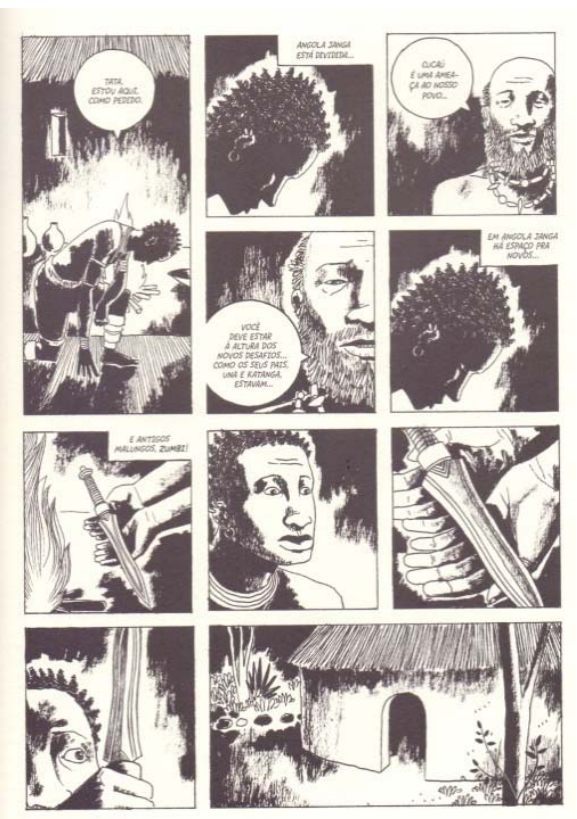

Imagem 3 - D’SALETE, Marcelo. Angola Janga: uma história de Palmares. São Paulo: Veneta, 2017, p. 147.

Já Zumbi é narrado na história como um líder guerreiro que é definido por lutar contra a dominação portuguesa que se apresentava sob a forma de expedições militares e sob constante interferência da economia de plantation escravista e a civilização católica portuguesa, dominada por senhores de engenho, nas práticas culturais quilombolas de Palmares. Essa interferência senhorial minou as possibilidades de êxito do acordo de paz de Ganga-Zumba com Recife e dividiu em duas facções o quilombo: os que defendiam o acordo de paz em desagregação (interpretados como os antigos malungos ${ }^{4}$ ), e os que apoiavam Zumbi como uma liderança de oposição frontal ao domínio da metrópole portuguesa (compreendidos como os novos).

Seguindo os princípios desenvolvidos por Bodo von Borries (2016, p. 32-33) em relação à "burdening history", essa biografia em quadrinhos passa de uma tentativa de reconciliação que buscava superar o sofrimento e a rivalidade para uma narrativa de vingança e rivalidade. Mas estes dois tipos de história difíceis estão cognitivamente enquadradas em uma narrativa histórica subalterna dos perdedores pautados na esperança de uma rememoração histórica.

\footnotetext{
${ }^{4}$ Malungo significa companheiro ou camarada. Era o termo com o qual os escravizados se tratavam durante a travessia no navio negreiro (D'SALETE, 2017, p. 417). Se interpretarmos esse termo como uma das formas de constante antropológica pautada no novo humanismo de Jörn Rüsen (2015), podemos aproximar malungo (Palmares e outros quilombos) das ideias de companheiro (Brasil), parce (Colômbia) de uma busca por uma relação de amizade de reconhecimento mútuo e igualitário.
} 
Outra narrativa biográfica em quadrinhos traz a experiência das revoltas sociais ocorridas durante a regência no Brasil imperial. A obra "Balaiada: a guerra do Maranhão", dos quadrinistas Iramir Araujo, Ronilson Freire e Beto Nicácio (2009) narra a história dos sujeitos escravizados e libertos que lutaram contra o sistema escravocrata no Maranhão.

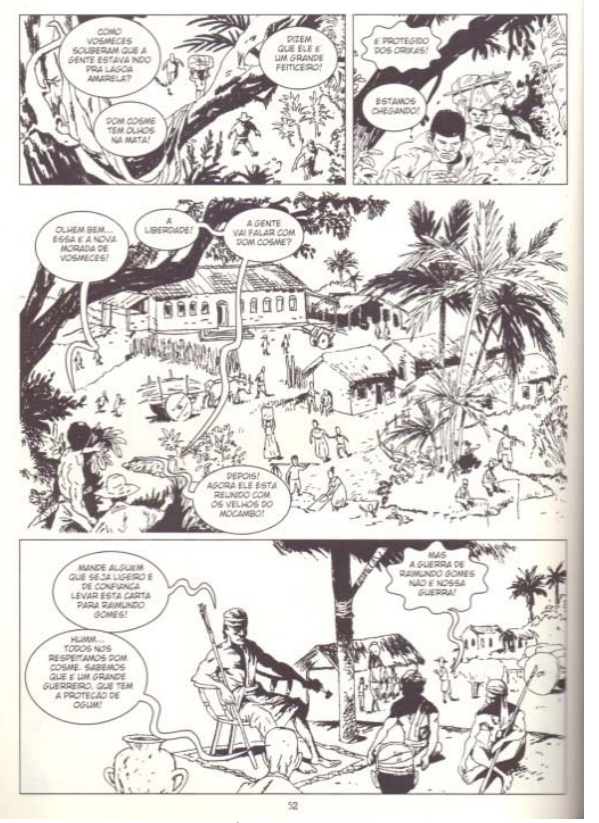

Imagem 4 - ARAUJO, Iramir; FREIRE, Ronilson; NICÁCIO, Beto. Balaiada: a Guerra do Maranhão. São Luís: ed. Do Autor, 2009, p. 52.

A história em quadrinhos narra as contradições existentes entre os ex-escravizados aquilombados da revolta da Balaiada e os combatentes de classe baixa e média baixa comandados predominantemente por afro-brasileiros livres (ARAUJO; FREIRE \& NICÁCIO, 2009). Esses últimos tinham como estratégia cooptar as elites provinciais maranhenses contra o governo central brasileiro. Já os combatentes quilombolas tinham como objetivo a eliminação do sistema escravista no Maranhão. O que radicalizou a rebelião foi o fato de que a maioria dos combatentes era composta por uma coluna de três mil escravizados fugidos dos engenhos e dos quilombos da província (ANDREWS, 2014, p. 107-108). 


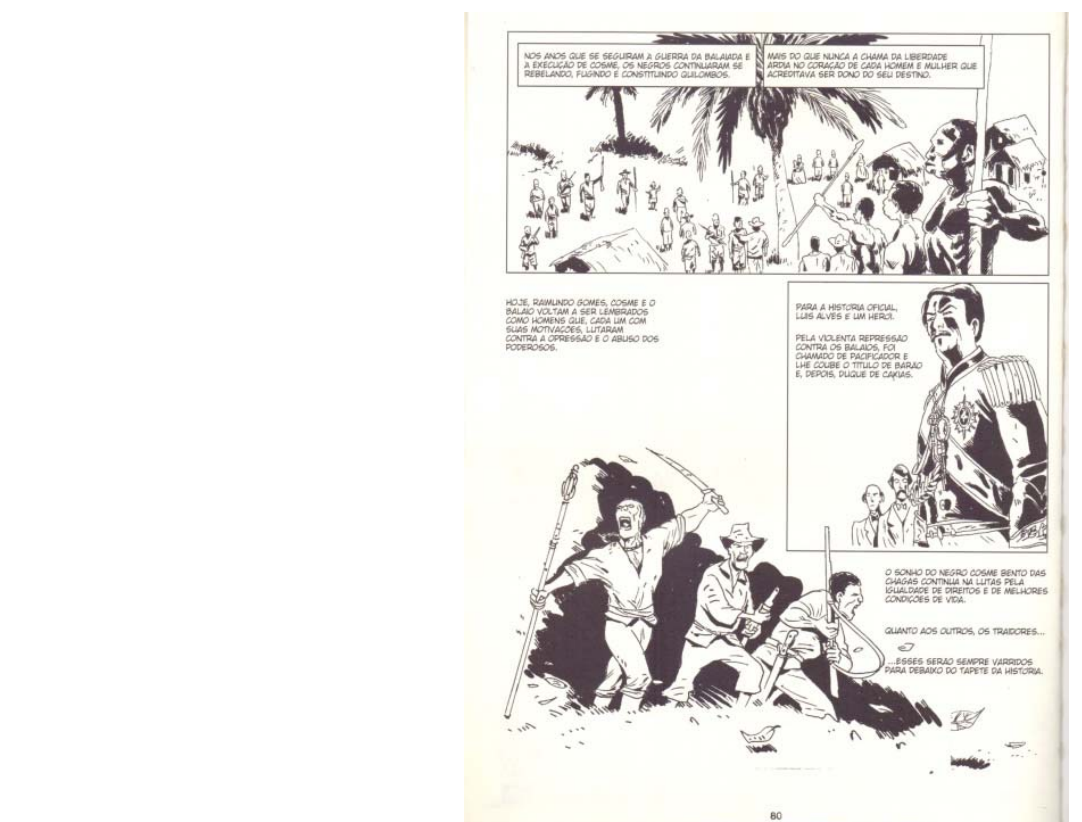

ARAUJO, Iramir; FREIRE, Ronilson; NICÁCIO, Beto. Balaiada: a Guerra do Maranhão. São Luís: ed. Do Autor, 2009, p. 80.

A repressão das tropas oficiais e a resistência dos escravizados levaram a perdas irreparáveis tanto para o governo da província do Maranhão quanto para os rebeldes. Oitocentos rebeldes conseguiram fugir da captura e formaram outros quilombos que foram reprimidos durante mais de uma década (ANDREWS, 2014, p. 108). Tal como na história em quadrinhos Angola Janga, em Balaiada é apresentada como uma contranarrativa subalterna que busca reabilitam uma rememoração histórica de perdedores que são transformados em heróis, sem buscar uma reconciliação com o passado. Isto porque a construção narrativa (Raimundo Gomes, Cosme Bento e Balaio) desses heróis populares se dá na oposição à história dos vencedores (representado Luis Alves, o Duque de Caxias transformado em herói pela história oficial brasileira do século XIX) pautada no cinismo do poder (BORRIES, 2016, p. 32-33).

Chibata! João Cândido e a revolta que abalou o Brasil, de autoria de Hemeterio e Olinto Gadelha, é uma biografia que conta a história de João Cândido, o popularmente chamado de o Almirante Negro, e da revolta da Chibata de 1910 de um ponto de vista humanista. Narrada a partir de uma estética expressionista marcada pela cor preta, esta história é construída a partir de documentos liberados na década de 2000 pela Marinha brasileira. É, portanto, uma história em quadrinhos biográfica de caráter historiográfico. 


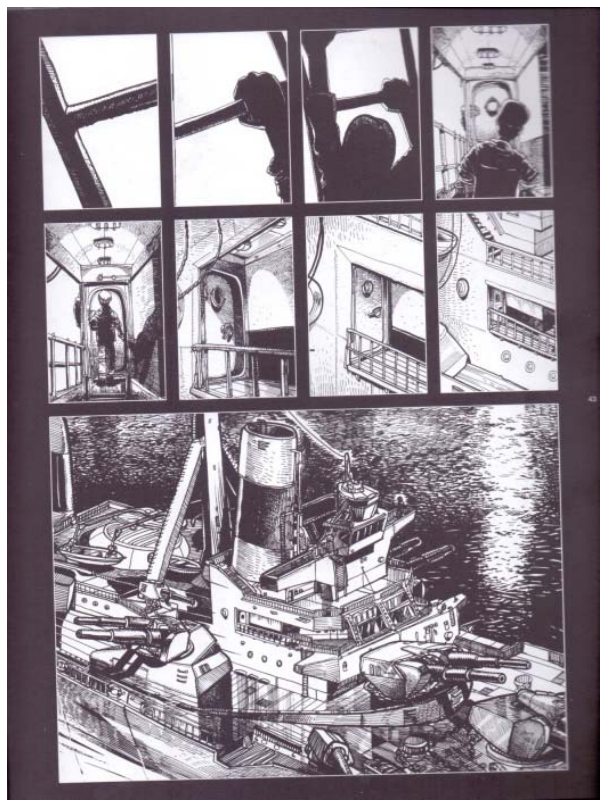

Imagem 5 - HEMETERIO \& GADELHA, Olinto. Chibata! João Cândido e a revolta que abalou o Brasil. São Paulo: Conrad, 2008, p. 43.

Nesta história, os quadrinistas buscam apresentar a revolta da Chibata como um ato político que rememora a rebelião do encouraçado Potemkin vinculada à revolução russa de 1905. Na história em quadrinhos tanto os enquadramentos da imagem do navio Minas Gerais (embarcação em que João Cândido liderou a revolta) remetem ao filme Encouraçado Potemkin (1925), de Sergei Eisenstein, quanto as assertivas de João Cândido remetiam que a insurreição que comandou foi inspirada naquela revolução. Isso porque os maus tratos dos oficiais superiores da Marinha aos marinheiros afro-brasileiros se assemelhavam às condições desumanas que russos sofriam nas mãos da oficialidade czarista.

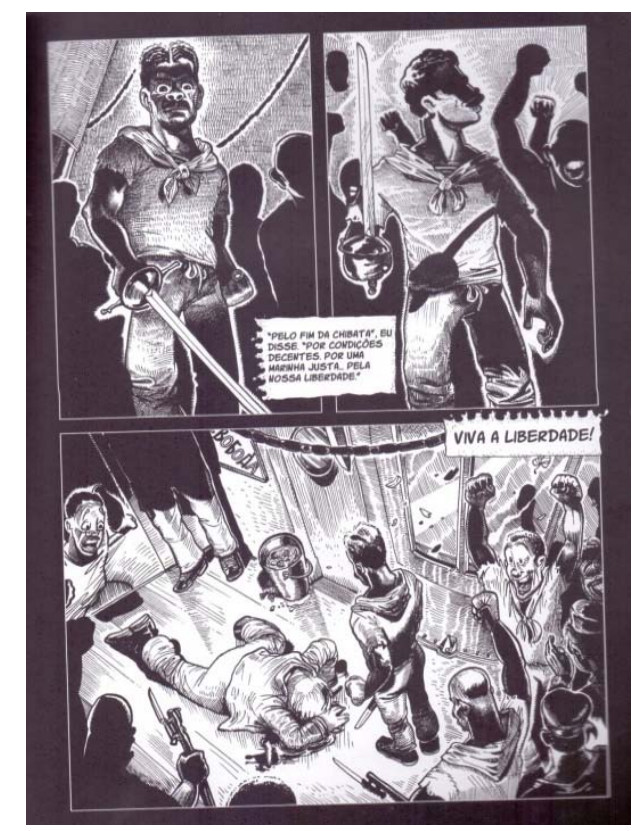


Imagem 6 - HEMETERIO \& GADELHA, Olinto. Chibata! João Cândido e a revolta que abalou o Brasil. São Paulo: Conrad, 2008, p. 83.

Nesse sentido, o enredo narra a revolta da Chibata como uma espécie de kairós, que para Jörn Rüsen (2007, p. 148-150) significa um tempo pleno, onde a representação do acontecimento histórico dá sentido de plenitude ao passado e ao futuro. Isto porque este artefato da cultura histórica narra uma experiência do tempo que reúne "a alteridade histórica e a utopia que transcende a história". A remissão às dores dos castigos físicos que sofriam marinheiros afrodescendentes infringidas pela oficialidade submetida a Hermes da Fonseca, que se assemelhavam às da escravidão, quanto à rememoração da revolução russa de 1905 buscam uma reconciliação com um passado de lutas em prol de uma humanidade igualitária.

A próxima narrativa biográfica que trago das experiências de resistência dos afrolatinos está ligada à Colômbia. Na narrativa Benkoz: la espiga dorada, de autoria de JeanPaul Zapata (2017), é contada a história de um jovem afro-colombiano alcunhado Benkoz. Este jovem, Julián Dominguez, foi um órfão e cego que viveu sua infância e parte da juventude no pueblo (povoado) de San Basilio de Palenque ${ }^{5}$, povoado da cordilheira central dos Andes colombianos, e depois, nos anos 2000, em Bogotá.

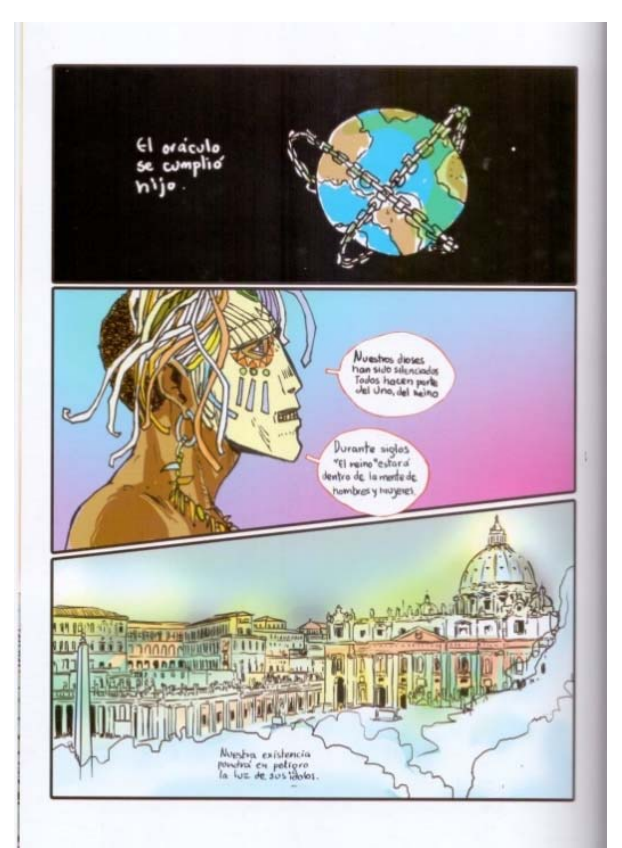

Imagem 7 - ZAPATA, Jean-Paul. Benkoz. La Espiga dorada. Bogotá/Colômbia: Puntagraphic, 2017, s/p.

5 Palenques são os equivalentes colombianos aos quilombos na América portuguesa e comunidades quilombolas no Brasil republicano. 
O jovem Julián Dominguez se tornou uma lenda urbana em Bogotá como o maior dançarino de break colombiano e passou a se autoproclamar herdeiro do legado de Benkos "Domingos" Biohó, um guerreiro africano escravizado que se tornou o rei de seu palenque na América colombiana (Vice-reino de Nova Granada) no século XVII. A primeira parte dessa história em quadrinhos colombiana guarda muitas semelhanças com Angola Janga ao narrar a historicidade que levou o rei guerreiro Zumbi ao domínio de Palmares.

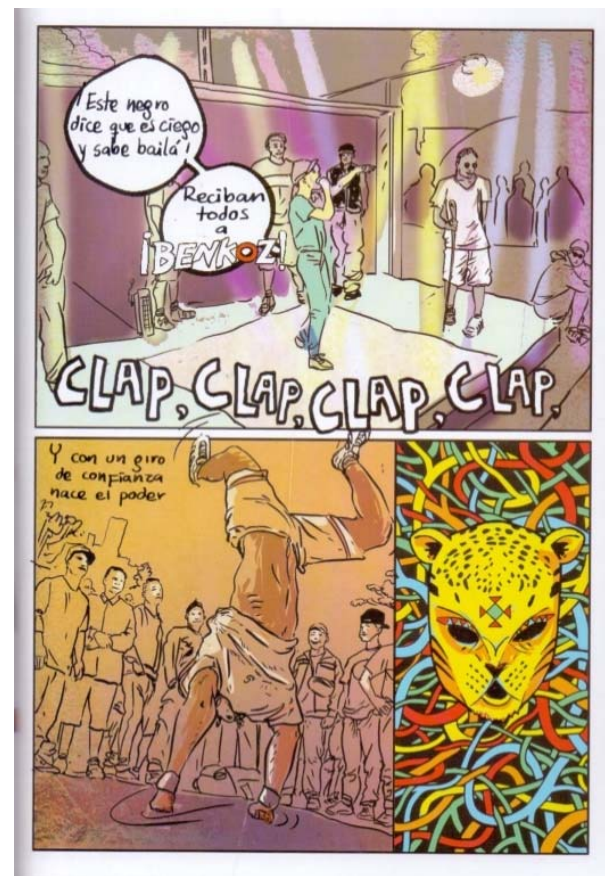

Imagem 8 - ZAPATA, Jean-Paul. Benkoz. La Espiga dorada. Bogotá/Colômbia: Puntagraphic, 2017, s/p.

Na segunda parte da narrativa gráfica é apresentada a ascensão artística de Benkoz na cena cultural de Bogotá e a vinculação de orientação de sentido histórico da luta deste artista de rua que fazia parte dos excluídos afro-latinos da sociedade colombiana e que, a partir de 2001, transcende de sua situação de pobreza para se tornar um intelectual que tem consciência de sua história. Priorizando a dimensão estética da cultura histórica, Jean Zapata constrói uma narrativa que dá passos firmes em direção à mutualidade, ao buscar construir histórias novas, plausíveis e compatíveis possibilitando o reconhecimento mútuo entre afrocolombianos, criollos e indígenas, e a aceitação e internalização mútua na própria história (BORRIES, 2016, p. 41). Isso por meio de uma estrutura de sentimentos pautada em uma cultura jovem que permite o diálogo intercultural entre diversas formações identitárias.

b) Histórias em quadrinhos que personalizam as experiências (auto)biográficas de sujeitos que vivenciaram os processos revolucionários e da resistência armada na América Latina 
O segundo tipo de histórias em quadrinhos (auto)biográficas se refere às experiências do passado de latino-americanos que viveram no campo utópico da construção de uma sociedade igualitária em países da América Latina, seja por meio da participação revolucionária, seja através da denúncia a violência das elites dessas nações. Investigo aqui, portanto, biografias gráficas que personalizam as narrativas históricas sobre os processos revolucionários tais como os de Cuba, assim como da resistência armada vinculada à denúncia da violência política na Colômbia.

Começo a análise desse tipo por uma história em quadrinhos (auto)biográfica que apresenta uma narrativa pessimista em relação ao processo revolucionário cubano: Cuba: minha revolução, de Inverna Lockpez e Dean Haspel (2013). É uma das narrativas históricas gráficas publicadas por uma transnacional dos quadrinhos. Neste caso, a DC Comics (pertencente à Warner Bros), por meio do selo Vertigo, voltado para o público jovem e adulto. Tenho como hipótese que a publicação por este tipo de editora explica o viés ideológico liberal antirrevolucionário e antissocialista desta história em quadrinhos autobiográfica.

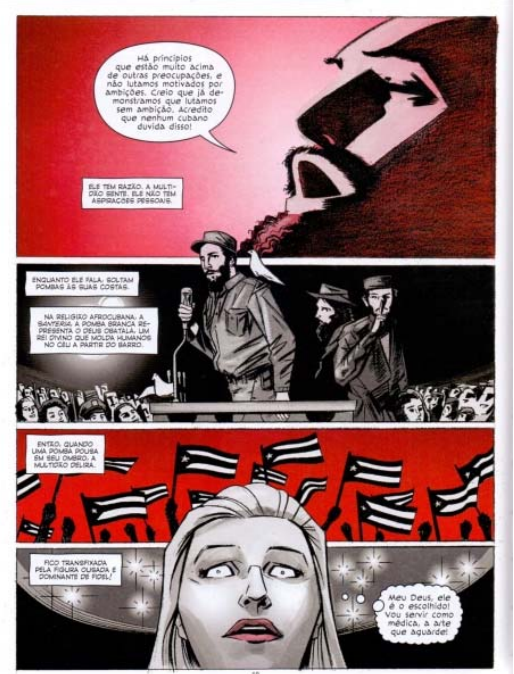

Imagem 9 - LOCKPEZ, Inverna; HASPIEL, Dean \& VILLARRUBIA, José. Cuba: minha revolução. Barueri-SP: Panini Books, 2013, p. 18.

Essa narrativa gráfica conta a história de Sonya (Inverna) a partir da perspectiva dos cubanos exilados dos Estados Unidos da América. Sonya era uma pintora filha de médicos da elite cubana. Essa personagem histórica, na narrativa, é apresentada como uma militante que venerava Fidel Castro e hipnotizada por seus discursos políticos televisionados durante a revolução de 1959 (LOPCKEZ; HASPIEL \& VILLARRUBIA, 2013, p. 18). Abandona a pintura 
para se tornar enfermeira. A mudança de seu posicionamento político se dá quando ela cuida de seu ex-namorado, que era um dos cubanos que invadiram a Baía dos Porcos com fracassado o apoio militar estadunidense (fato que Sonya desconhecia encanto o curava). Como resultado, a polícia secreta cubana a prendeu e a torturou para que ela delatasse as supostas relações e informações que tinha com a $\mathrm{CIA}^{6}$.

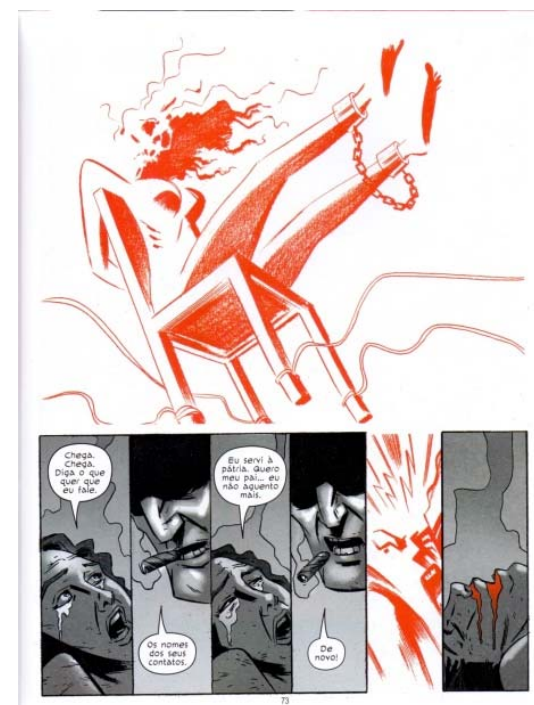

Imagem 10 - LOCKPEZ, Inverna; HASPIEL, Dean \& VILLARRUBIA, José. Cuba: minha revolução. Barueri-SP: Panini Books, 2013, p. 73.

A transformação da protagonista numa antirrevolucionária narrada esteticamente por meio de representações advindas de uma cultura histórica ligada à sociedade do espetáculo (DEBORD, 1997) que priorizam as imagens de tortura física e de degradação humana na prisão. Portanto, a autobiografada passa de uma jovem ingênua que apoiava a revolução nacionalista de Fidel Castro (momento apresentado de maneira idílica pelos autores) para uma mulher atemorizada que odiava o que os liberais chamavam de uma stalinização da sociedade cubana sob a égide daquele líder (agora um ditador) após a invasão da Baía dos Porcos.

A escolha dessa história em quadrinhos nesta investigação se dá porque mesmo pertencendo a uma editora do "main stream" estadunidense, está num selo reservada a histórias com gêneros alternativos da DC Comics, tais como a (auto)biografia. Outro motivo é que pode ser lida, do ponto de vista dos conservadores liberais como uma contranarrativa à narrativa mestra sobre a revolução cubana construída sobre o regime comunista de Fidel

\footnotetext{
${ }^{6}$ Central Intelligence Agency. Agência Central de Inteligência dos Estados Unidos da América que tem sua ação nos países externos à nação.
} 
Castro. A intenção de incluir este artefato da cultura histórica é apresentar os necessários contrapontos para verificar a força de plausibilidade de uma explicação histórica. No caso, que as narrativas históricas gráficas latino-americanas sobre os processos revolucionários e sobre a denúncia relativas à violência política perpetrada por suas elites são contranarrativas em relação à narrativa mestra neoliberal e midiática da vitória definitiva do capitalismo e do estado de direito de representação política na América Latina.

Essa narrativa pertence ao primeiro tipo de história difícil proposta por Bodo von Borries (2016, p. 33), ou seja, uma história hostil baseada em um modelo de vingança (inimizade herdada) vinculadas a investigações empíricas da cultura histórica para a construção de uma autobiografia vingadora.

Como contraposição a essa narrativa liberal investigo o manhwa ${ }^{7}$ oriental Che: uma biografia, do quadrinista coreano Kim Yong-Hwe (2006). Originalmente esse manhwa foi publicado por uma das maiores editoras coreanas, Daiwon C.I. Portanto, pertence ao rol das histórias em quadrinhos lidas por dezenas ou centenas de milhões de jovens pelo planeta, fazendo parte da cultura juvenil contemporânea.

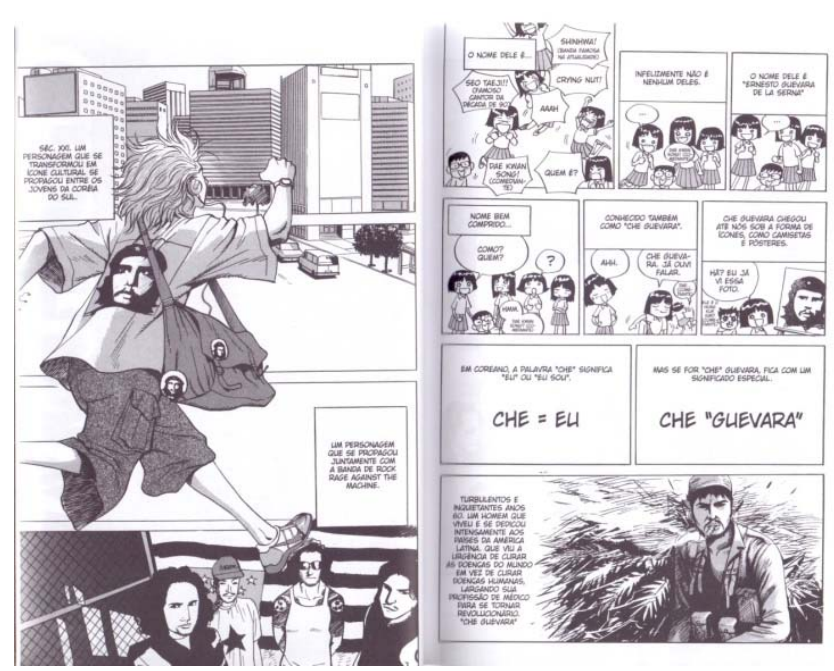

Imagem 11 - YONG-HUE, Kim. Che: uma biografia. São Paulo: Conrad, 2006, s/p.

A história começa ao apresentar a influência da imagem de Che Guevara na cultura juvenil coreana dos anos 2000 devido a uma música da banda de rock Rage Against the

\footnotetext{
${ }^{7}$ Manhwas são as histórias em quadrinhos coreanas que apesar de proximidades estéticas e estilísticas com os mangás japoneses não podem ser confundidos com estes (CAMPOS, 2017). Por exemplo, ao contrário dos mangás os manhwas são lidos do modo ocidental (da esquerda para a direita).
} 
Machine. E também pelo fato significativo de que Che, em coreano, significa "eu" ou "eu sou", o que facilitou a identificação dos jovens desse país com o guerrilheiro latinoamericano.

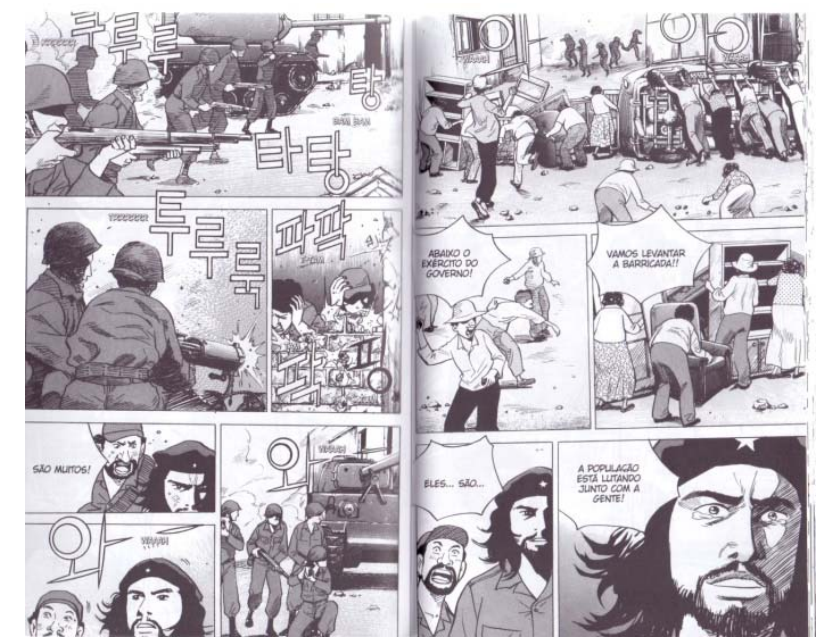

Imagem 12 - YONG-HUE, Kim. Che: uma biografia. São Paulo: Conrad, 2006, s/p.

A narrativa histórica gráfica biografa as viagens de Che Guevara pela América Latina e principalmente a ação e comando da guerrilha por focos na Sierra Maestra em Cuba, onde treina e conscientiza os camponeses a partir da concepção do "homem novo", pois para ele o povo cubano não podia ser tratado como "bois" ou "porcos" (YONG-HWE, 2006, s/p), tal como acontecia com a ditadura de Fulgêncio Batista. Também narra a tomada do quartel de Moncada com o apoio popular ao enfrentamento contra o exército assim como sua participação no governo revolucionário cubano.
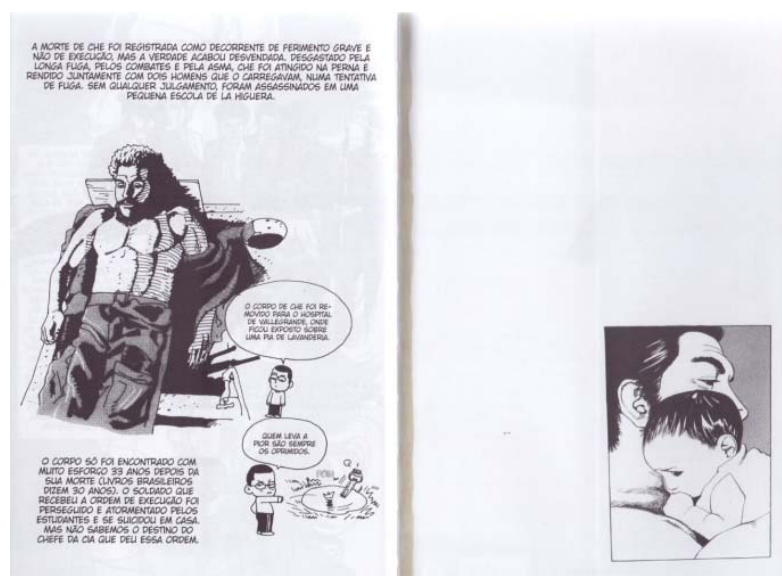

Imagem 13 -YONG-HUE, Kim. Che: uma biografia. São Paulo: Conrad, 2006, s/p.

A biografia em quadrinhos termina com a execução de Che Guevara em uma escola de La Higuera, na Bolívia, em outubro de 1967. E esta história que narra a vida de um guerrilheiro latino-americano de um ponto de vista utópico e humanista acaba com um ato 
de revolta no diálogo de uma criança coreana: "O corpo de Che foi removido para o hospital de Villegrande, onde ficou exposto sobre uma pia de lavanderia. Quem leva a pior são sempre os oprimidos". Na página ao lado uma esperança. Um quadrinho com Che abraçando um bebê recém-nascido. A história em quadrinhos biográfica em questão, enquanto história difícil (BORRIES, 2016, p. 33), passa da superação de uma história de vingança para se tornar história subalterna dos perdedores que reconstroem uma rememoração histórica heroica.

A última biografia em quadrinhos que investigo é Gabo: memorias de uma vida mágica, de Oscar Pantoja, Miguel Bustos, Felipe Camargo e Tatiana Córdoba (2017). Esse artefato da cultura histórica latino-americana biografa as experiências do escritor colombiano Gabriel García Márquez e o contexto da história colombiana valorizando momentos que articulam a práxis vital do romancista e a história de violência das elites da Colômbia e da América Latina.

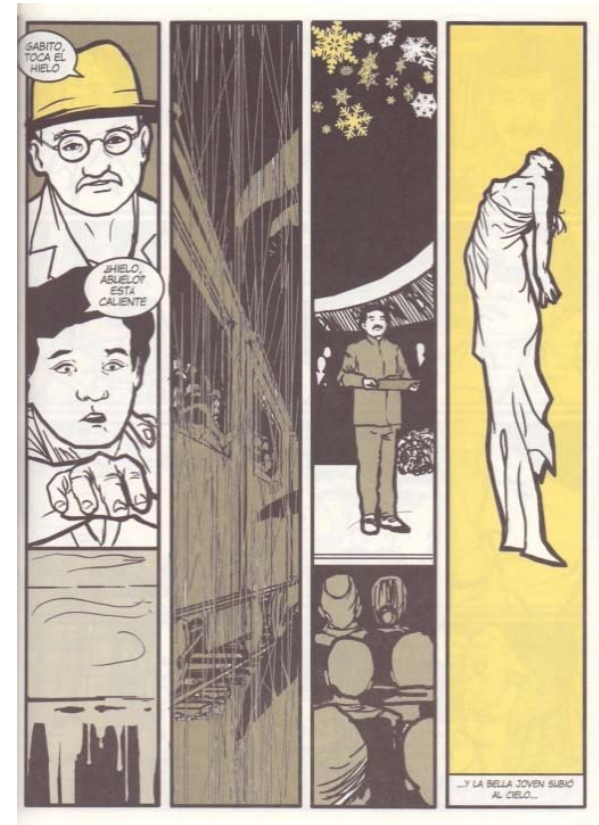

Imagem 14 - PANTOJA, Oscar; BUSTOS, Miguel; CAMARGO, Felipe \& CÓRDOBA, Tatiana. Gabo: memórias de uma vida mágica. Bogotá: Rey Naranjo editors, 2017, p. 9.

Os quadrinistas valorizam a dimensão estética da narrativa por meio de tons amarelos, mas principalmente, porque ao narrarem a história de García Márquez e da Colômbia interpõem flashs visuais de momentos memoráveis do romance Cem Anos de Solidão (MÁRQUEZ, s/d), tal como a belíssima cena da jovem que ascende aos céus (PANTOJA; BUSTOS; CAMARGO \& CÓRDOBA, 2017, p. 9). Assim, a biografia produzida a 
partir de critérios historiográficos dialoga com imagens marcantes de passagens do referido romance que valeu, em 1982, a Gabo, o Prêmio Nobel de Literatura.

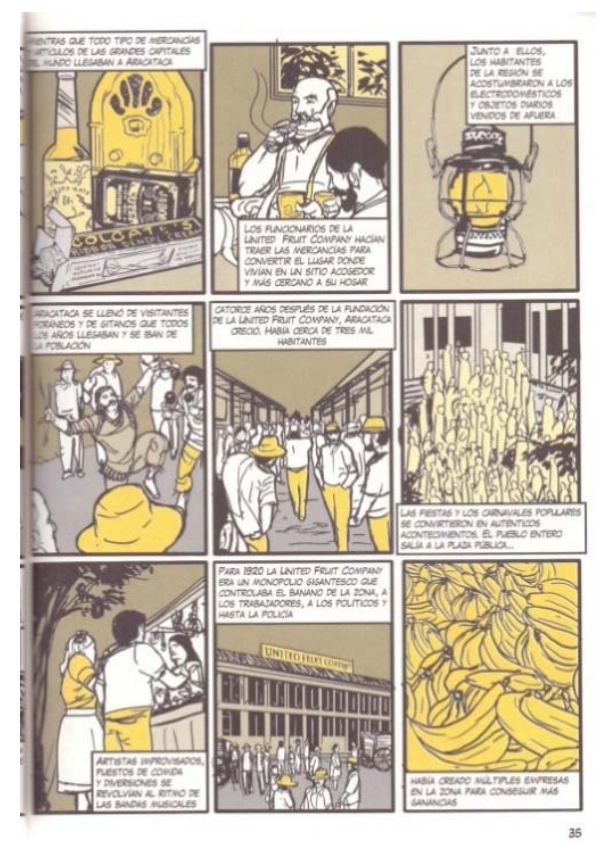

Imagem 15 - PANTOJA, Oscar; BUSTOS, Miguel; CAMARGO, Felipe \& CÓRDOBA, Tatiana. Gabo: memórias de uma vida mágica. Bogotá: Rey Naranjo editors, 2017, p. 35.

Um dos grandes momentos dessa narrativa histórica gráfica acontece quando uma passagem do romance Cem Anos de Solidão e um dos episódios de maior sofrimento dos trabalhadores rurais na história da Colômbia. Acontece em um local próximo de Aracataca, no departamento de Magdalena, cidade natal de Gabo, e também a referência histórica para a mítica Macondo do romance. Na década de 1920, a cidade e a região caribenha do norte da Colômbia eram completamente dominadas política, social e economicamente pela empresa de bananas estadunidense Unidet Fruit Company. 


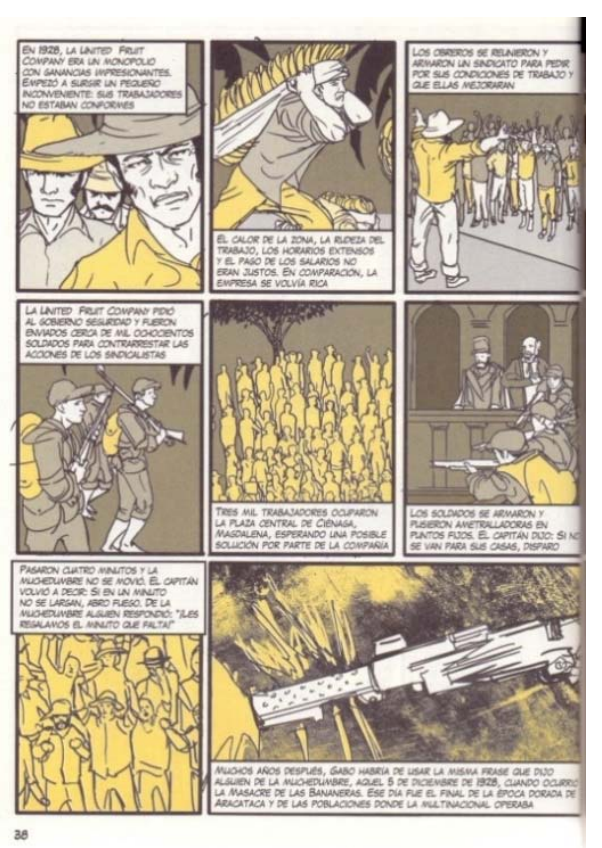

Imagem 16 - PANTOJA, Oscar; BUSTOS, Miguel; CAMARGO, Felipe \& CÓRDOBA, Tatiana. Gabo: memórias de uma vida mágica. Bogotá: Rey Naranjo editors, 2017, p. 38.

A história em quadrinhos narra, assim como em Cem Anos de Solidão, que os trabalhadores rurais e urbanos se organizaram em um sindicato para combater as condições desumanas de trabalho. A empresa estadunidense impõe a proteção dos empresários pelo governo contra os trabalhadores, de modo que o estado enviou o exército colombiano para exterminar três mil trabalhadores na praça central de Ciénaga, em 5 de dezembro de 1928. Esse fato, esquecido pela história oficial colombiana da época, passou a ser conhecido pelos trabalhadores locais como "La Masacre de Las Bananeras".

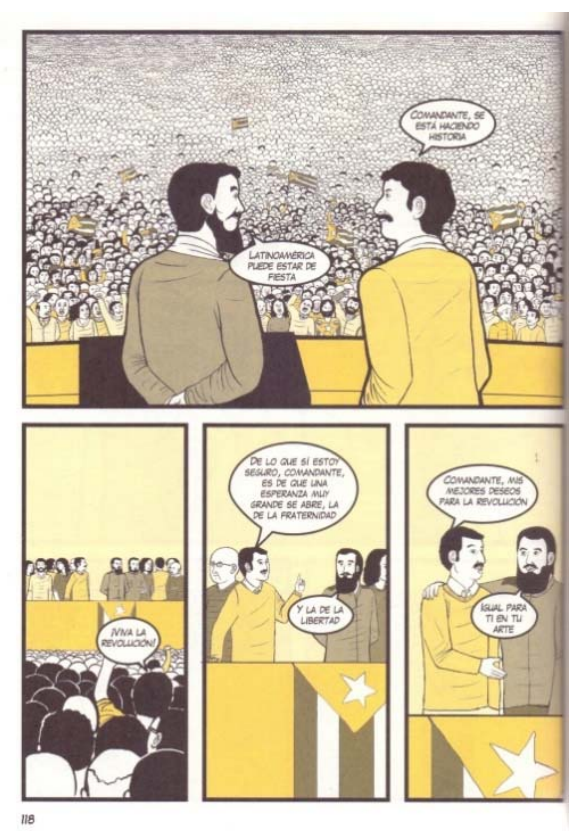

Imagem 18 - PANTOJA, Oscar; BUSTOS, Miguel; CAMARGO, Felipe \& CÓRDOBA, Tatiana. Gabo: memórias de uma vida mágica. Bogotá: Rey Naranjo editors, 2017, p. 118. 
Em contrapartida, a Revolução Cubana de 1959 é narrada nessa história em quadrinhos na perspectiva de uma reconciliação com o passado violento da América Latina a partir de sua superação. A Revolução Cubana é apresentada nessa biografia em quadrinhos como um tempo pleno, conforme a perspectiva da ideia de kairós em Jörn Rüsen (2007). Isso porque junto com a experiência estética do romance Cem Anos de Solidão, o processo revolucionário cubano fornece sentido de orientação temporal para as experiências violentas do passado das elites capitalistas contra os trabalhadores latino-americanos, e a possibilidade utópica de um futuro igualitário para a humanidade.

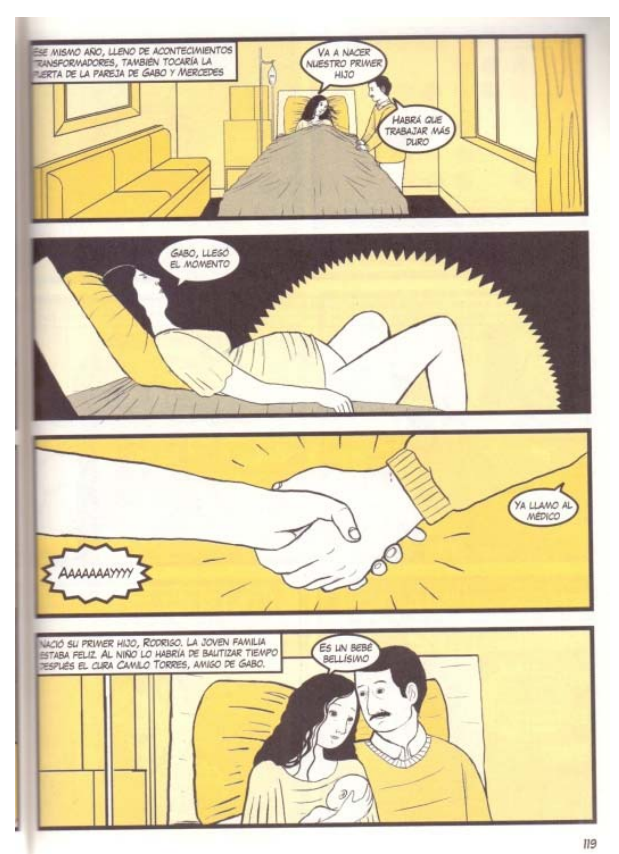

Imagem 19 - PANTOJA, Oscar; BUSTOS, Miguel; CAMARGO, Felipe \& CÓRDOBA, Tatiana. Gabo: memórias de uma vida mágica. Bogotá: Rey Naranjo editors, 2017, p. 119.

As belas imagens em quadrinhos referentes ao nascimento do filho de Gabo é uma narrativa histórica que apresenta os primeiros passos para uma reconciliação histórica com o passado de violência e sofrimento (BORRIES, 2016, p. 41). Isto porque busca abolir as falsificações históricas e os mitos tendenciosos. Busca-se um distanciamento do passado, mas não seu esquecimento. Mas também passos intermediários foram dados, pois essa narrativa biográfica busca uma direção em relação aos outros na procura de um caminhar juntos ao lutar para que todos os que sofreram com perda de parentes e amigos durante a violência tenham o direito de saber o que ocorreu naquele passado ainda oculto. É uma busca das condições da formação de sentido histórico para um futuro comum entre latinoamericanos. 


\section{Considerações finais}

Com conclusão, predominam entre as biografias em quadrinhos investigadas uma concepção de sentido de orientação temporal vinculada ao terceiro tipo de história difícil proposta por Bodo von Borreis (2016, p. 32), qual seja, a história oculta e subalterna dos perdedores e a esperança de uma rememoração histórica por meio de uma memória heroica de seus líderes e movimentos. Essa concepção predomina nas narrativas históricas gráficas sobre Zumbi dos Palmares, na América portuguesa do século XVII, os líderes da Balaiada no Maranhão, no Brasil imperial do século XX, e na vida de João Cândido, o Almirante Negro ou o Dragão do Mar, líder da revolta da Chibata, no Brasil da primeira república do século XX, e a biografia de Benkoz, na Colômbia do século XXI, no que se refere à memória histórica dos afro-latinos. Essa última história em quadrinhos narra de forma evidente o modo como o sentido de orientação temporal se dá na história de um jovem afro-colombiano contemporâneo, e como experiências do passado mobilizam a cultura jovem.

A concepção da rememoração histórica dos perdedores também predomina nas narrativas gráficas sobre sujeitos históricos latino-americanos relacionadas à Revolução Cubana de 1959 e as histórias de violência. Isso vale para a biografia de Che Guevara, e da relação de amizade e crença no projeto de future comum entre Gabriel García Márquez e Fidel Castro. Portanto, as biografias em quadrinhos de sujeitos latino-americanos tendem a ser contranarrativas em relação aos discursos hegemônicos das elites conservadoras e capitalistas dos países da América Latina.

No entanto, também encontrei uma história em quadrinhos, a única autobiografia investigada que se pauta na despersonalização das histórias dos personagens históricos, no caso de Inverna Lopckez (Sonya), são narradas de modo que o contexto histórico seja esteticamente dimensionado como uma estrutura determinista pautado na cultura histórica voltada para uma sociedade do espetáculo. Essa despersonalização se dá por conta do viés ideológico liberal e conservador da narrativa que parte do ponto de vista dos cubanos exilados nos Estados Unidos da América, que compreende a sociedade cubana pósrevolucionária como um estado totalitário. Felizmente, essa concepção despersonalizadora foi a possibilidade que menos apareceu neste inventário de histórias em quadrinhos sobre os as experiências históricas dos latino-americanos que lutaram pela igualdade humana. 
Há, portanto, histórias em quadrinhos estruturadas como narrativas historiográficas que biografam as experiências de sofrimento e luta pela igualdade humana de sujeitos históricos esquecidos pela historiografia tradicional. E destaco que concepções de superação de histórias difíceis e enfretamento do fardo da história a partir da luta pelo reconhecimento mútuo também apareceram como nas narrativas gráficas de Benkoz e Gabo. Isto porque estas histórias buscam uma reconciliação sincera com o passado e com a alteridade histórica no presente com vistas à construção de um future comum e igualitário.

\section{REFERÊNCIAS BIBLIOGRÁFICAS}

ANDREWS, G. R. América Afro-Latina, 1800-2000. São Carlos-SP: EdUfscar, 2014.

ARAUJO, Iramir; FREIRE, Ronilson; NICÁCIO, Beto. Balaiada: a Guerra do Maranhão. São Luís: ed. Do Autor, 2009.

ARFUCH, L. O espaço biográfico: Dilemas da subjetividade contemporânea. Rio de Janeiro: EDUERJ, 2010.

BAKHTIN, Mikhail. M. Problemas da poética de Dostoiévski. Rio de Janeiro, Forense Universitária, 1997.

BAKHTIN, M. M. Estética da criação verbal. São Paulo: Martins Fontes, 2000.

BORRIES, B. Lidando com histórias difíceis. In: SCHMIDT, M. A.; FRONZA, M.; NECHI, L. P. (orgs). Jovens e consciência histórica. Curitiba: W.A. Editores, 2016, p. 32-54.

CAMPOS, J. M. Aprendizagem histórica a partir dos manhwas: um diálogo entre a história e as histórias em quadrinhos sul coreanas. (Trabalho de conclusão de curso em Licenciatura de História). Cuiabá: UFMT, 2017.

DEBORD, G. A sociedade do espetáculo: comentários sobre a sociedade do espetáculo. São Paulo: Contraponto, 1997.

D'SALETE, M. Angola Janga: uma história de Palmares. São Paulo: Veneta, 2017.

FREITAS, R. R. Aprendizagem histórica de jovens estudantes no envolvimento com o jogo eletrônico: Um estudo da relação intersubjetiva entre consciência histórica e cultura histórica. 170p. (Dissertação de Mestrado em História) - Programa de Pós-Graduação em História, Universidade Federal de Mato Grosso, Cuiabá, 2017.

GUNDERMANN, C. Jenseits von Asterix: Comics im Geschichtsunterricht. Schwalbach: Wochenschau Verlag, 2007.

HEMETERIO; GADELHA, O. Chibata! João Cândido e a revolta que abalou o Brasil. São Paulo: Conrad, 2008.

JORDANOVA, L. History in practice. New York: Oxford university Press, 2006. 
LEJEUNE, P. Le Pacte Autobiographique. Paris: Editions de Seuil, 1996.

LOCKPEZ, I; HASPIEL, D.; VILLARRUBIA, J. Cuba: minha revolução. Barueri-SP: Panini Books, 2013.

LUKÁCS, G. História e consciência de classe: estudos sobre a dialética marxista. São Paulo: Martins Fontes, 2003.

LUKÁCS, G. Marxismo e teoria da literatura. 2. ed. São Paulo: Expressão Popular, 2010.

MÁRQUEZ, G. G. Cem anos de solidão. 25 ed. Rio de Janeiro: Record, s/d.

MCCLOUD, S. Reinventando os quadrinhos. São Paulo: Makron Books, 2006.

PANTOJA, O.; BUSTOS, M.; CAMARGO, F.; CÓRDOBA, T. Gabo: memórias de uma vida mágica. Bogotá: Rey Naranjo editors, 2017.

RÜSEN, J. ¿Qué es la cultura histórica?: Reflexiones sobre una nueva manera de abordar la historia, 1994. [Unpublished Spanish version of the German original text in K. Füssmann, H.T. Grütter and J. Rüsen, eds., 1994. Historische Faszination. Geschichtskultur heute. Keulen, Weimar and Wenen: Böhlau, p. 3-26]. Disponível em: http://www. culturahistorica.es/ruesen/cultura_historica.pdf. Acesso: em 27 mai. 2011,

. A razão histórica: Teoria da história: os fundamentos da ciência histórica. Brasília: UnB, 2001. 2007.

. História viva: Teoria da História III: formas e funções do conhecimento histórico, Brasília: UnB,

. Didática da história: passado, presente e perspectivas a partir do caso alemão. In: SCHMIDT, M. A., BARCA, I.; MARTINS, E. R. (Orgs.). Jörn Rüsen e o ensino de História. Curitiba: Ed. UFPR, 2010, p. $23-40$

Aprendizagem histórica: Fundamentos e paradigmas. Curitiba: W. A. Editores, 2012.

. Cultura faz sentido: orientações entre o ontem e o amanhã. Petrópolis: Vozes, 2014.

. Teoria da História: uma teoria da história como ciência. Curitiba: EDUFPR, 2015.

SALIBA, E. T. As imagens canônicas e o Ensino de História. In: SCHMIDT, Maria Auxiliadora; CAINELLI, Marlene Rosa. III Encontro Perspectivas do Ensino de História. Curitiba: Aos Quatro Ventos, 1999, p. 434-452.

- Na guinada subjetiva, a memória tem futuro? In: ROCHA, Helenice; MAGALHÃES, Marcelo; GONTIJO, Rebeca (orgs.). A escrita da história escolar: memória e historiografia. Rio de Janeiro: FGV, 2009, p. 51-63.

SCHMIDT, M. A. Cognição histórica situada: que aprendizagem histórica é essa? In: SCHMIDT, M. A.; BARCA, I. (Orgs.). Aprender história: perspectivas da educação histórica. ljuí: Editora UNIJUÍ, 2009, p. 21-51.

VERSACl, R. This book contains graphic language: comics as literature. New York/London: The Continuum International Publishing Group, 2007.

WERTSCH, J.; ROZIN, M. La Revolución Russa: versions oficiales e no oficiales. In: CARRETERO, Mario; VOSS, J. F. Aprender y pensar la historia. Buenos Aires: Amorrortu, 2004, p. 121-150.

WITEK, J. Comic books as History: the narrative art of Jack Jackson, Art Spiegelman and Harvey Pekar. Jackson: University Press of Mississipi, 1989. 
YONG-HUE, K. Che: uma biografia. São Paulo: Conrad, 2006.

ZAPATA, J-P. Benkoz. La Espiga dorada. Bogotá/Colômbia: Puntagraphic, 2017. 